\title{
Adjuncts for Care of the Surgical Patient
}

Editor

SIDNEY L. BOURGEOIS Jr

\section{ATLAS OF THE ORAL AND MAXILLOFACIAL SURGERY CLINICS OF NORTH AMERICA}

www.oralmaxsurgeryatlas.theclinics.com

Consulting Editor

RICHARD H. HAUG

September 2015 • Volume 23 - Number 2 